\title{
Working
}

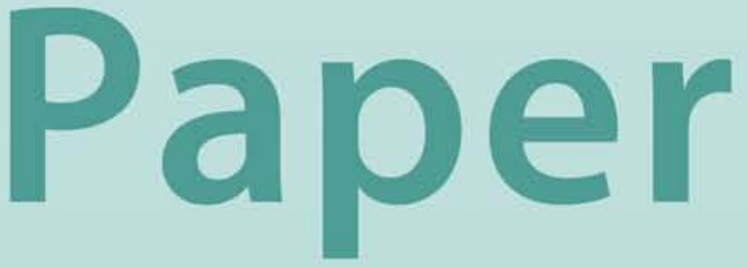




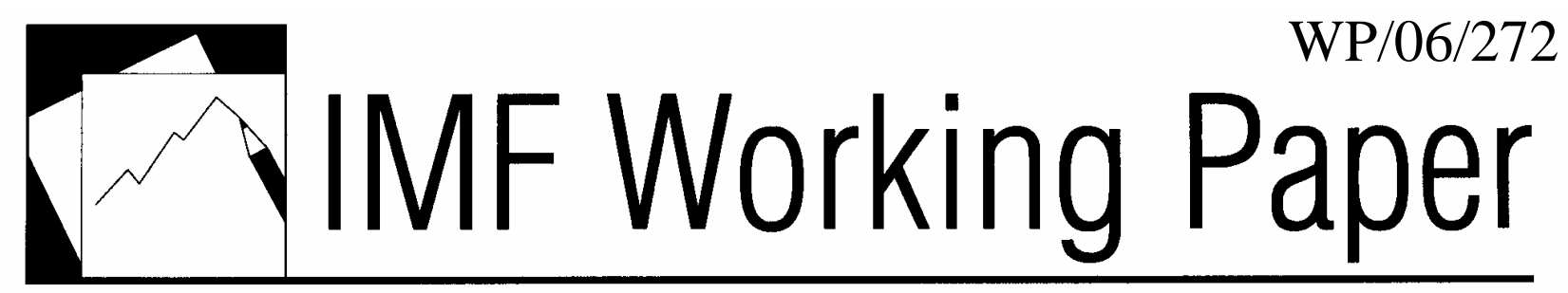

Is Asia Prepared for an Aging Population?

Peter S. Heller 


\title{
IMF Working Paper
}

Fiscal Affairs Department

\section{Is Asia Prepared for an Aging Population?}

\author{
Prepared by Peter S. Heller
}

December 2006

\begin{abstract}
This Working Paper should not be reported as representing the views of the IMF. The views expressed in this Working Paper are those of the author(s) and do not necessarily represent those of the IMF or IMF policy. Working Papers describe research in progress by the author(s) and are published to elicit comments and to further debate.

Many Asian countries (such as China, Singapore, Korea, Thailand, Malaysia, Indonesia, India, and the Philippines) will experience a significant aging of their populations during the next several decades. This paper explores how these aging Asian countries are addressing and anticipating the challenges of an aging society. It suggests that Asia's preparedness for an aging population is decidedly mixed. While growth policies have been successful, much work is still needed in many countries to establish an adequate and farsighted policy framework in the areas of pensions, health insurance, and labor market policies.
\end{abstract}

JEL Classification Numbers:I11, I12, J11, J26, N35, O52

Author’s E-Mail Address: pheller@imf.org 


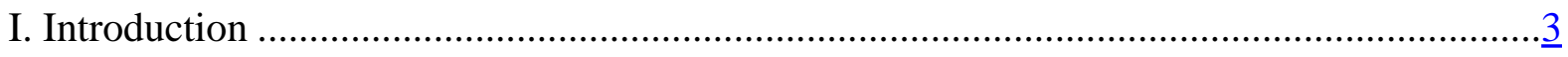

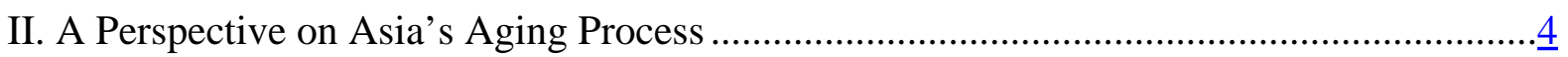

A. Demography ....................................................................................................

B. Asia's Economies ......................................................................................

C. Present Social Insurance Systems in Asia...............................................................

III. How Well-Positioned are Asian Countries to Address the Challenges of an

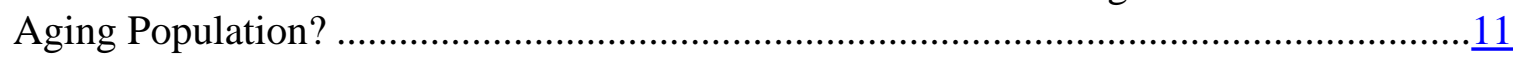

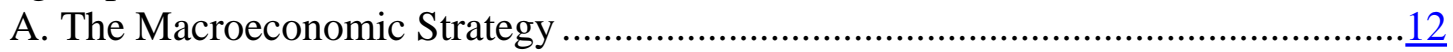

B. Microeconomic Strategies....................................................................................

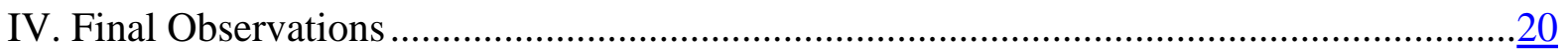

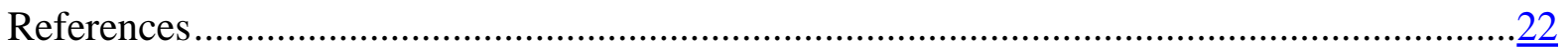

Figures

1. Old Age Dependency Rate in Selected Asian Countries, 2000-50........................................ $\underline{5}$

2. Very Elderly Dependency Rate in Selected Asian Countries, 2000-50 …………….............

3. Urbanization Rate in Selected Asian Countries, 2000-30 ......................................................

Appendix

1. Summary Characteristics of Asian Pension and Health Care Systems................................... 


\section{INTRODUCTION}

The challenges faced by industrial countries in the West and Japan with the prospective retirement of the "baby boom" generation are well recognized. Generous and well-developed social insurance systems - for pensions and medical care-now confront the "perfect demographic storm' arising from an unanticipated demographic transition to higher longevity and lower fertility rates. ${ }^{1}$ Since the cost of these systems had been assumed to be financed by a growing working age population, the sharp drop in fertility that has prevailed since the early 1960s has shrunk the size of the pool of workers available to support the cost of social transfers. Industrial governments thus face the unpleasant choice of either raising taxes and contribution rates or cutting back on the promises being made to future retirees in order to ensure fiscal sustainability. Even putting aside the issue of fiscal sustainability, these countries face the prospect of slower economic growth and the social and economic challenges posed by the large growth of the elderly and very elderly segments of their populations.

Asia too has experienced a similar demographic phenomenon. This has been particularly the case for its more developed countries-The Republic of Korea (hereafter referred to as Korea), Singapore, Hong Kong, Special Administrative Region, (hereafter referred to asHong Kong SAR), Thailand, and Malaysia as well as a rapidly growing China. Although lagged two decades or so behind the industrial countries, the sharp decline in fertility ratessometimes as a result of deliberate policy initiatives as in China and Korea-and rising longevity rates will result in a rising elderly dependency ratio (EDR) by 2020-30, largely offset by a declining youth dependency ratio (YDR).

The obvious questions to be posed are how these aging Asian countries are positioned and what policy dilemmas their societies will face in terms of addressing the challenges of an aging society. Specifically, how will their future economic growth rates respond to the aging of the work force and the ultimate slowing in its growth? Are their social insurance systems well adapted to confront the issues posed by a rising EDR and the types of medical cost pressures associated with rising longevity or are their significant lacunae in their social insurance policy frameworks? Will they face significant fiscal challenges akin to those in the industrial countries? Are there any Asia-specific challenges that arise from their 'position in the queue' as ' 2 nd - round' aging societies? Is there reason for concern about China 'getting old before it gets rich?' This paper considers these questions, focusing on China, Hong Kong SAR, India, Indonesia, Korea, Malaysia, the Philippines, Singapore, and Thailand.

\footnotetext{
${ }^{1}$ Private defined benefit systems in the U.S. and the U.K. have been subject to a different type of "perfect storm,” viz., the combination of poor investment returns, low interest rates for valuing liabilities, and the demographic trends noted above.
} 


\section{A Perspective on Asia’s Aging Process}

A perspective on the preparedness of a country to address, in the future, the challenges of a relatively aged population requires consideration of both its present demographic structure and its economic policies. The former provides an insight into the likely pace of demographic change and the economic opportunities afforded by the transitional bulge in the size of the labor force. Consideration of the latter reveals whether current economic policies are supportive of a rapid pace of economic growth during the period before the elderly become a significant share of the population.

\section{A. Demography}

Writers on the 'demographic dividend' associated with the transition from high to low fertility and mortality rates have principally focused on two facets of the process (see Bloom and Canning, 2005). The first is the large pool of potentially employable labor of working age in the first phase of the process; the second is the potential for high savings rates by these workers, particularly as they move into their most productive working years and as the consumption support needs of their young dependents lessen. Both facets provide an enormously important window of opportunity for rapid and buoyant economic growth through an enhanced labor force and high investment rates. The opportunities afforded by high savings rates relate to achieving both a higher aggregate per capita income level by the time the population becomes aged and the building up of a stock of assets, both real and financial (and internal and external), that can be drawn upon to help finance the consumption needs of an elderly population.

The flip side of the transition of course is the eventual subsequent movement of the population structure toward significantly higher EDRs (and smaller YDRs) as the rate of growth of the working age population falls and the share of the longer-lived retired population (defined by some arbitrary retirement age-usually 60 or 65) rises. For the industrial countries, it is around 2010 when the rapid shift toward a higher share of the elderly begins, and issues of old age support begin to bite, increasing the pressures for lower savings rates and higher consumption rates.

Asian countries sit astride this demographic transition at various points (see Figure 1). Some, such as Hong Kong SAR, Korea and Singapore, are much more advanced in the process, with the EDR converging to those levels observed in industrial countries as early as 2030, and further dramatic increases in subsequent years. Korea, for example, is said by OECD sources to have the fastest aging of any country in the world. Its rapid aging process is also illustrated by the speed at which the share of the very elderly (over age 80 ) in the population is rising; that share is projected to almost quadruple, rising to industrial country levels. in the next 15 years (see Figure 2). China's and Thailand's demographic transition follow, with their demographic dividend period lasting through about 2035-40, and with both the elderly and very elderly shares rising quickly thereafter. Malaysia follows closely: its demographic dividend period is expected to last slightly longer through 2045. India, Indonesia and the 
Philippines are next, with a high share of the elderly only beginning to emerge sometime after 2050.

China's situation is unusual in several respects (see Jackson and Howe 2004). Its size obviously commands attention. The number of its elderly already dwarfs that of many industrial countries. But more importantly, the pace of aging in its urban centers (where about a third of the population lives) has been far greater than in the rural areas, reflecting both sustained lower fertility and higher longevity. Even with rural to urban migrants included as part of the urban population, the closing of the demographic dividend period may occur much earlier in urban China - say during 2025-30 - than in rural China, when it is expected to occur around 2035-40. Many critical policy issues will rest on how these urbanrural differentials are addressed both across and within provinces and at the family and policy levels. ${ }^{2}$ These issues will be compounded by the rapid pace at which urbanization is

Figure 1. Old Age Dependency Rate in Selected Asian Countries, 2000-50 1/

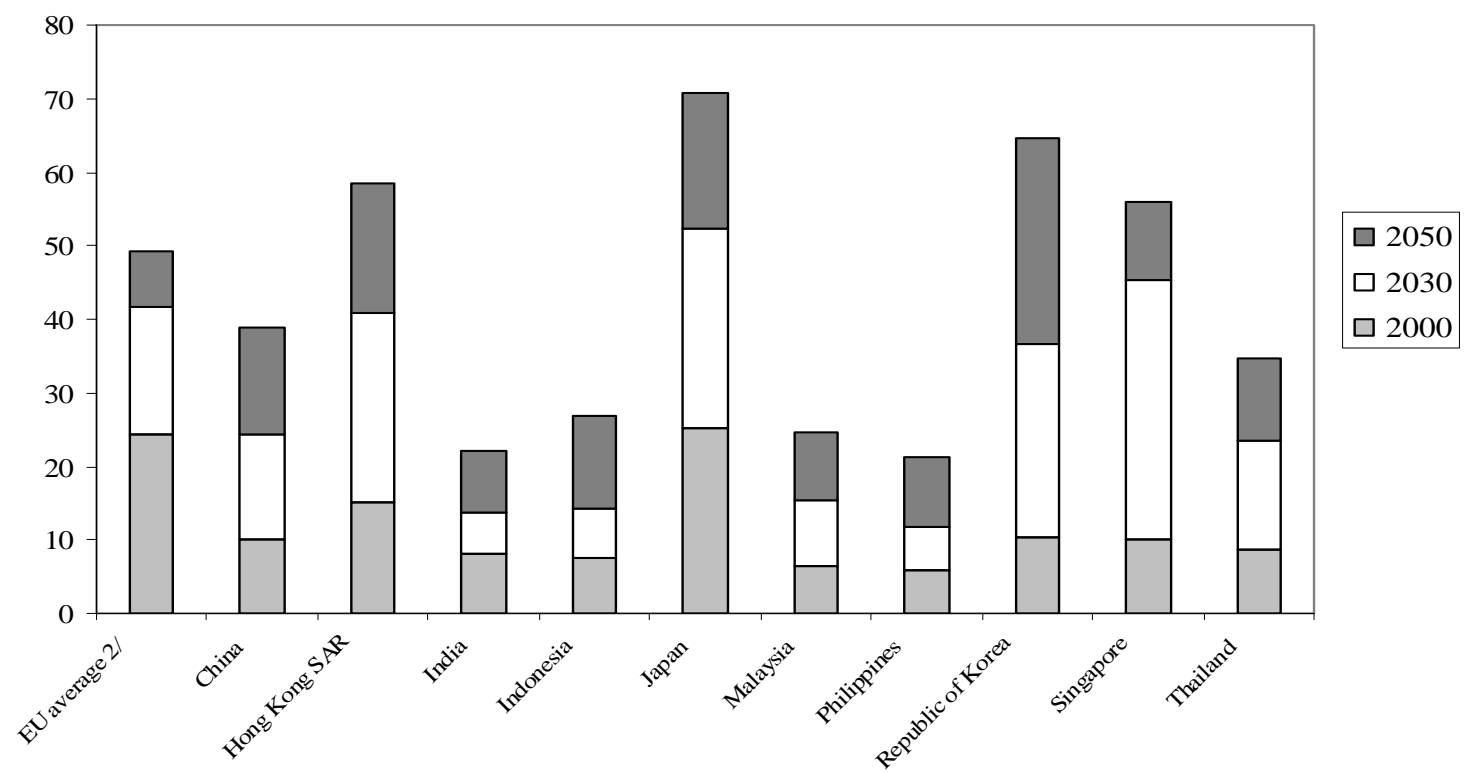

Sources: UN Population Division (2005)

1. Data refer to projected shares of the population aged 65 and above relative to the population aged 15-64 under the assumption of medium levels of fertility rates.

2. EU average refers to the simple average of data for the following six countries: Belgium, France, Germany, Italy, Netherlands, and the United Kingdom.

\footnotetext{
${ }^{2}$ The role of urban migrants will be particularly important, whether they are urban taxpayers (effectively facilitating some intergenerational transfers to urban elderly) or a source at least of remittances (if not of direct care giving) to elderly relations still living in the rural areas.
} 
Figure 2. Very Elderly Dependency Rate in Selected Asian Countries, 2000-50 1/

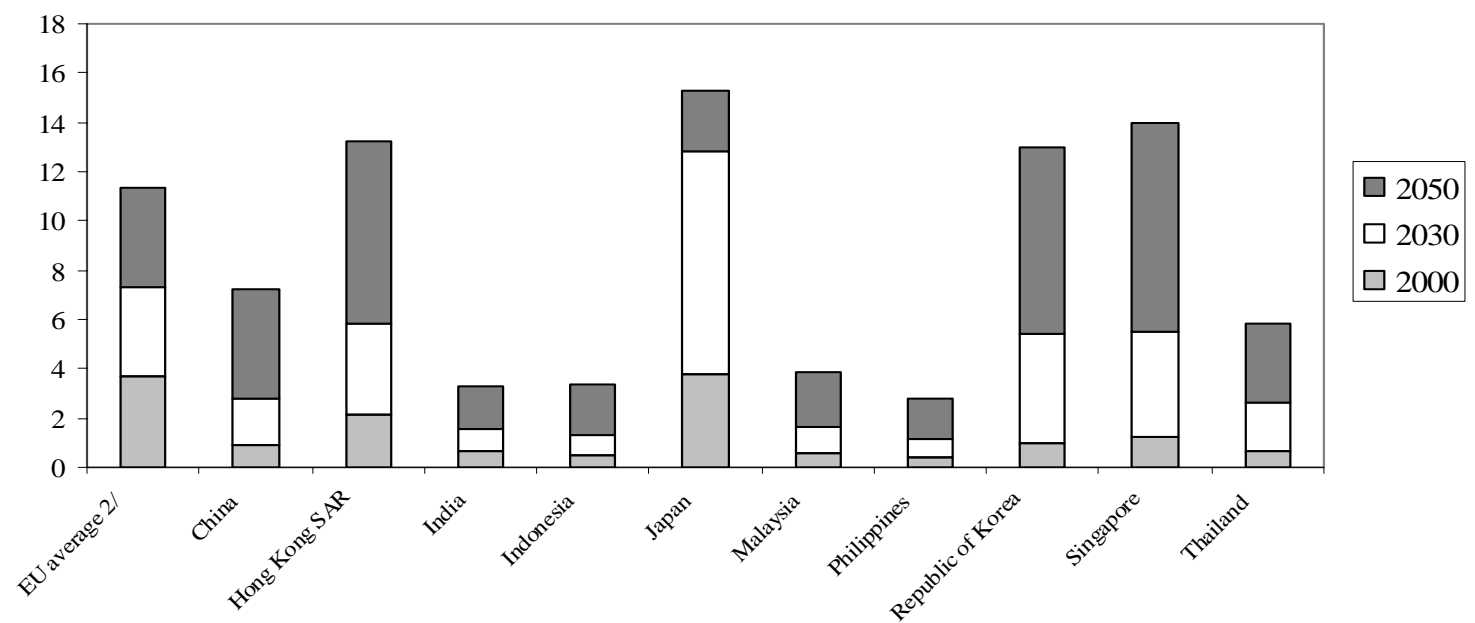

Source: UN Population Division (2005)

1. Data refer to projected shares of the population aged 80 and above in the total population under the assumption of medium levels of fertility rates.

2. EU average refers to the simple average of data for the following six countries: Belgium, France, Germany, Italy, Netherlands, and the United Kingdom.

Figure 3. Urbanization Rate in Selected Asian Countries, 2000-30 1/

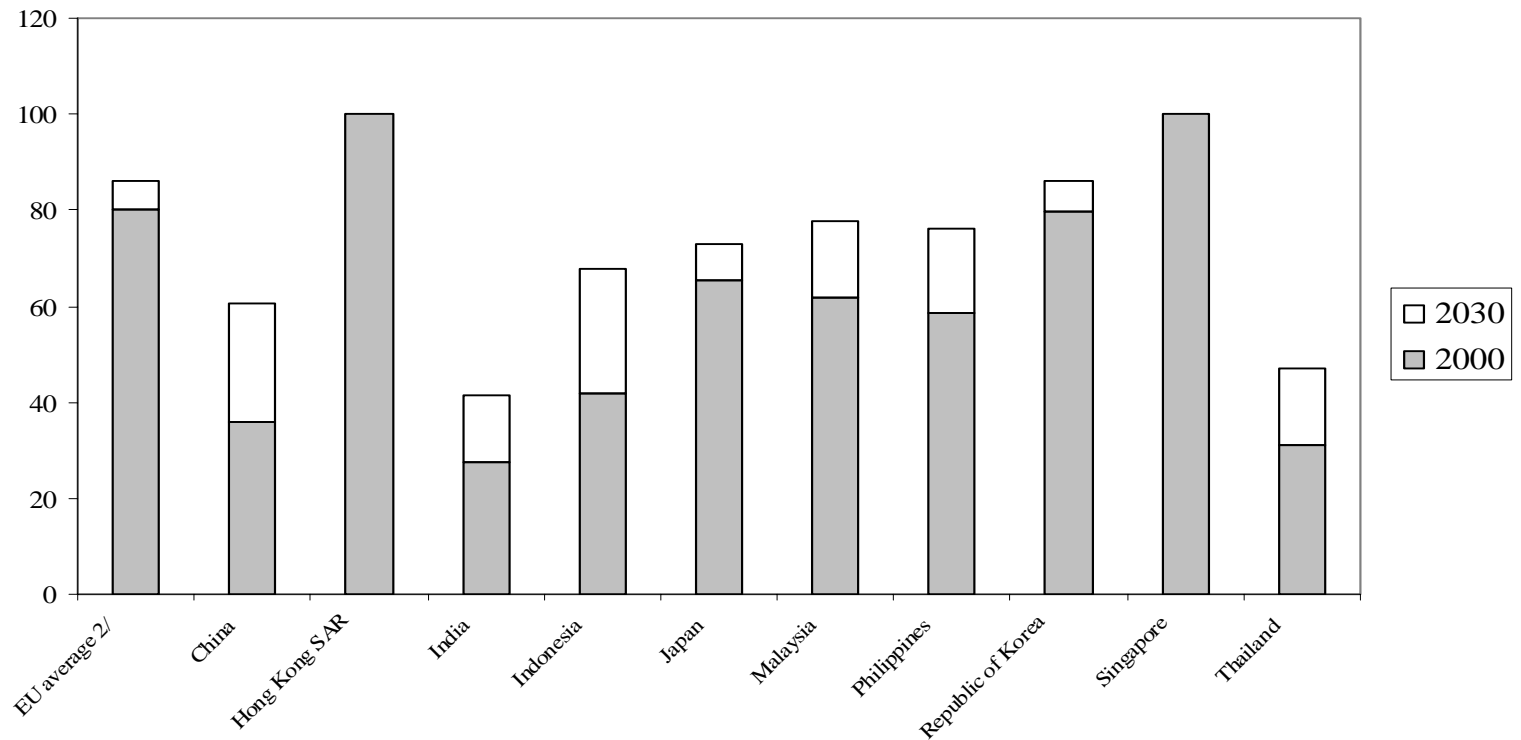

Source: UN Population Division (2006)

1. Data refer to projected share of urban population in the total population under the assumption of medium levels of fertility rates.

2. EU average refers to the simple average of data for the following six countries: Belgium, France, Germany, Italy, Netherlands, and the United Kingdom. 
occurring in China, where the share of the population in the urban areas is projected to rise from a third to more than half in the next decade and a half (Figure 3). The oft-mentioned gender-gap - the shortage of women relative to men (due to differences in the birth rates of boys and girls) — will also be an important issue to be reckoned with in China. It will raise concerns not only over the scarcity of potential wives but also over the scarcity of potential 'caregivers' for the elderly.

\section{B. Asia's Economies}

Asia's economies also illustrate the possibilities afforded by the demographic dividend. Certainly Hong Kong SAR, Korea and Singapore are countries that richly took advantage of the potential of their demographic dividend by maximizing their labor utilization and achieving high national savings rates, as reflected in per capita incomes either at or approaching industrial country levels (particularly if incomes are defined in terms of Purchasing Power Parity (PPP)). Malaysia and Thailand are well in the ranks of middle income countries, particularly if per capita GDP is defined in PPP terms. They have also pursued a development strategy built on exploiting their demographic dividend, with a resulting strong performance in economic growth. China, coming from much further behind economically and despite its extraordinarily rapid recent economic growth and high savings and investment rates, still faces many challenges if it is to create productive jobs for its large labor pool in coming years. Despite its similarity to Malaysia and Thailand in its stage of demographic transition, it has an income level much closer to that of the Philippines, with dramatic differences between urban and rural areas, the latter areas being much on par with Asia's other low income countries.

The Philippines, India and Indonesia are in the lower ranks of Asia's middle income countries. They have relatively low incomes per capita, national savings rates at least 10 percent of GDP below the aforementioned Asian countries, and the potential for labor absorption from the rural sector and productive investments in human capital still to be fully exploited.

Will these countries be ‘old before they are rich?' Korea and Singapore are already converging on per capita income levels among the upper middle income country group. By the time their elderly dependency ratios begin to mount, their aggregate per capita income levels in GDP terms will be in the range experienced by many industrial countries today. Countries such as Indonesia, Malaysia, and the Philippines, can expect, at current growth rates, to see their per capita income levels rise to a third to two-thirds of current EU-6 levels by the time their elderly dependency rates converge to current EU-6 levels (around midcentury). In PPP terms, these per capita income levels may prove closer to industrial country levels.

Most analysts expect China to continue to see dramatic economic growth. If its per capita income continues to rise at the pace expected during 2006-10, per capita GDP could quadruple by 2022 and grow by a factor of 8 by 2030, the year in which it matches today's European elderly dependency ratio. This would yield a per capita GDP level about 40 percent 
of that of the EU-6 countries today ${ }^{3}$, and an even higher level if measured in PPP terms.. These results of course mask the fact that the sharp differentials in income levels within China between urban and rural areas are likely to persist, with the result that the income status of many of China's elderly will be far below what might be suggested by aggregate per capita income levels. In contrast, by the time India reaches today's elderly dependency ratio of the EU-6 countries - much later of course, say around 2050 - its GDP per capita would still be less than 20 percent of today's EU-6 per capita income level (though again higher in PPP terms).

Thus, for most of these countries, the challenge of accommodating an aged population will consist only in part of increasing aggregate income. A greater challenge will be to improve the distribution of income across generations, increase the willingness of younger generations to support the elderly, and create the political viability for the institutional mechanisms chosen to intermediate this intergenerational transfer.

\section{Present Social Insurance Systems in Asia}

Virtually all the Asian countries under discussion have wrestled with the issues involved in developing social insurance systems to manage the risks associated with retirement and medical care. The variety in the observed strategies principally reflects differences in national perspective and the specifics of each country's history and institutions. The appropriateness of these strategies in addressing the long-term demographic transition, including the prospects of an aging population, has probably been, at most, only a small factor in policy design.

Pension Systems: Two approaches to pension systems stand out. The first is that of the Central Provident Funds (CPF) of Singapore and Malaysia (and to a limited extent, Thailand) and the recently established (in 2000) Mandatory Provident Fund of Hong Kong SAR (see Asher and Nandy 2006b and Thillainathan 2004). These systems essentially use a 'defined contribution' (DC) approach. They contrast with the various civil service and private employer-based defined benefit (DB) schemes observed in Korea, Thailand, Philippines, and India. The CPF approach essentially involves prefunding particular, potentially large expenditure requirements before retirement (e.g., for housing, education and in some cases medical care) as well as people's income needs during retirement. It implies commensurately high national savings rates. The high mandatory savings rates (in the mid-30 percent range of wages up to a wage ceiling), coupled with reasonably effective investment strategies by the funds' financial managers for the significant accumulated assets in the funds, provide for a lump-sum payment at retirement, the eligible age of which ranges from 55 to $62 .{ }^{4}$ The

\footnotetext{
${ }^{3}$ The EU-6 countries comprise France, Germany, Italy, Poland, Spain, and the United Kingdom.

${ }^{4}$ The associated asset buildup in capital goods has been largely domestic but with some international diversification of asset holdings as well.
} 
replacement rate that would be entailed by the purchase of an annuity with this lump sum is still not generous however, ranging from 20-40 percent. Both systems entail the potential risk for households of using funds too early — albeit for legitimate needs before retirement — and for too limited a period after retirement. Because the funds can be drawn on before retirement, there is the risk that they will prove an inadequate retirement vehicle for many elderly. The threat applies to both partners of a couple, but the greatest threat is to widows who did not work outside of the home.

For the DB schemes, coverage ranges from being largely universal, as in Korea (at least in principle) and increasingly the Philippines, to covering at most 30 percent of the labor force- parts or all of the formal modern sector and workers in the civil service-in the other countries. Replacement rates for covered workers vary. For covered workers in Thailand, they are at most 30 percent. ${ }^{5}$ The DB schemes are largely PAYGO in structure, with only the Korea scheme carrying out some prefunding. This makes these schemes heavily reliant on their capacity to raise contribution rates from workers in the event of future operational deficits, making them particularly vulnerable to an increase in the EDR. For example, Thailand's Old Age Pension Fund (OAPF) scheme is expected to exhaust its reserves by mid-century. Achieving universal coverage can prove difficult. Korea's scheme took approximately 15 years from the time in which the National Pension scheme was introduced to the point that mandatory subscription was required. Moreover, about 15 percent of subscribers are not contributing to the scheme as required.

Relative to the others, China's pension system is very much in a state of flux, reflecting the dramatic structural transformation of China's economy over the last 20 years (see Asher et al 2005, Pi 2005, and Trinh 2006). In the urban areas, the government has begun to replace the fragmented pension system, for which state enterprises and the government have been responsible, with a three-pillar system involving a mandatory DB/PAYGO scheme as the first pillar, a mandatorily funded DC scheme as the second pillar, and a voluntary savings scheme as the third-pillar. The government is largely responsible for meeting pension liabilities to existing retirees and to those with vested rights.

The new schemes cover less than half the urban work force, however. Pooling rarely extends beyond the municipal level. Noncompliance is rife among employers, particularly in the private sector. The funds associated with the individual account system have been used by municipalities largely to finance pension payments to existing retirees. Indeed the urban pension system still appears to be underfunded. Optimistic estimates of the implicit 'legacy debt' associated with the previous urban pension system range from 50 to 150 percent of GDP and are even higher under more conservative assumptions. Moreover, recent examples of corruption in Shanghai in the management of the investments of pension fund assets give

\footnotetext{
${ }^{5}$ A mandatory provident fund exists for central government employees, teachers and some state enterprise employees. Although this adds some assets at retirement, the provisions force the withdrawal of a lump sum at retirement and do not encourage annuitization (Chaiyasoot, 2005).
} 
rise to concern about the adequacy of even available financial assets to meet future pension liabilities.

In the rural areas, the commune pension system, which previously provided retirement benefits to its members (albeit at very low income levels under the pre-market system), has fallen apart. It is being replaced, if at all, by minimal social safety net transfers. ${ }^{6}$ In sum, fewer than a quarter of China's workers are covered by the new pension scheme. High individual savings rates by Chinese workers may reflect their recognition of the limitations of the still-evolving formal retirement and medical insurance schemes.

Medical care: Health care systems are particularly difficult to categorize. Some countriesMalaysia, Hong Kong SAR, and Indonesia-are heavily reliant on budget-financed systems, which offer universal access to care in principle, but the quality of services effectively varies widely according to a household's income and place of residence (see WHO 2004, Wagstaff 2005, and Pillay 2005). Even where facilities for care are available in some countries (e.g., in rural China), the cost of care that must be borne out-of-pocket essentially limits effective access to quality health care. In some countries, the private sector may also be a key provider. This may reflect the inadequacies of the public health care system, as in India, or it may be an intrinsic element in the design of the medical care system, as in Thailand. In other countries, the private sector caters largely to a narrow segment of the population.

Korea, Thailand, and the Philippines have adopted a social health insurance system, though only the former two offer relatively universal coverage (see Kim 2005, Koh 2005, Yang 2005, Tangcharoensathien et al., 2005, and Jowett, 2005). Korea has also decided to introduce a scheme for long term care as of 2008. Universality in coverage does not necessarily imply full access to all possible medical services or low copayments. In Korea, effective copayments are quite high and the range of medical services covered remains limited. Singapore relies on the private financing of medical care, either directly by the household on an out-of-pocket basis or from employer-financed insurance, though it has several public schemes that partly address the challenge of obtaining catastrophic care and medical care for the indigent (see Asher and Nandy 2006a).

Before the market reforms of the 1980s, China provided universal medical care, albeit at differing levels of quality for the urban and rural areas and depending on the type of economic organization providing the care. This system collapsed in the 1980s with the introduction of the market economy, the breakdown of the rural communes, the growing importance of private enterprises, and the weakened state of many state-owned enterprises. As with pensions, the cost, availability and system of financing of medical care now varies dramatically, both between and within the urban and rural sectors. Medical spending has risen rapidly in China in the last two decades, fueled almost entirely by uncontrolled, largely

\footnotetext{
${ }^{6}$ Coverage of these transfers is very low. Since poor townships do not have the resources to finance them, the transfers are nearly nonexistent in those localities.
} 
supply-induced spending in public and private urban sector units involving the acquisition of high technologies and financed by the out-of- pocket spending of households. There is a network of public hospitals and clinics in both the urban and rural areas, but because government-financed allocations are tightly constrained, effective access to most medical services for much of the population is contingent on whether an individual can pay for diagnostic tests, drugs, and many kinds of treatment. ${ }^{7}$

In the urban areas, a basic employee medical insurance scheme has been introduced that involves a combination of a medical savings account system, limited risk pooling and health insurance. But coverage is only gradually being extended to private sector employees, most urban migrant workers are not covered, the benefits provided by the system are very limited, and there is costly cross-subsidization of many elderly retirees. In some urban areas, the government is also experimenting with the concept that has been called the Community Health Service. The CHS relies on community-based clinics that are partially financed by the government and are staffed by nurse practitioners and family physicians. They are intended to provide primary care to all individuals, including migrants, who reside in the urban areas. This scheme still relies on individual copayments for tests and drugs and individuals must pay significant charges for much of the care provided by public hospitals.

In the rural sector, government medical units provide care, but most of the costs are borne by households. Social health insurance is largely absent for 90 percent of rural residents. A new rural cooperative medical scheme is now being developed and aggressively expanded, but it remains poorly funded, is likely to cover only an additional 20 percent of the rural population, and is still voluntary and thus subject to adverse selection pressures. It also still requires copayments as high as 70 percent of the total medical bills on average, and makes users pay up front, essentially disqualifying the poor from accessing care and benefits under the scheme. Moreover, the scheme focuses on catastrophic health events. Access to essential health care remains entirely dependent on out-of-pocket payments.

\section{How Well-Positioned ARE Asian Countries to AdDRess the Challenges of an Aging Population?}

There are two principal aspects to a country's strategy in dealing with the prospect of a significant aging of its population in the future. The first is macroeconomic and entails the pursuit of a policy of rapid economic growth. A rise in saving and investment rates early in the demographic transition can facilitate the achievement of a much higher per capita income level by the time the demographic structure shifts. It allows a country room to meet the consumption needs of the larger share of the retired population while still satisfying the standard-of-living aspirations of those of working age. The second is microeconomic, relating to the institutional mechanisms and incentives that govern how this higher income

\footnotetext{
${ }^{7}$ For a general discussion of health sector issues in China see Yip and Hsiao 2001, Blumenthal and Hsiao 2005, United Nations Health Partners Group in China 2005, Tang, Cheng, and Xu, 2003 and WHO, 2005.
} 
ends up being distributed as between the working and retired portions of the population. Four broad strands of government policy bear on meeting the challenge of an aged population in the microeconomic sphere.

First, governments may influence or mandate individuals to provide for their old age security by smoothing their consumption over their lifetime; governments may also seek to provide some kind of protection to limit the likelihood of elderly destitution. As is evident in the Asian case, they can do this by explicitly mandating savings or by providing incentives to save or to make family transfers. ${ }^{8}$ The government can also introduce social insurance policies that entail an intergenerational pact providing for significant transfers from the working age population to retired households. Policies that enhance the productivity of savings - particularly those that strengthen the functioning of the financial sector-are also critical elements of policy in this regard.

Second, government policies may also seek to provide incentives to individuals and enable them to remain engaged in the labor force for a longer period as life expectancy increases. Promoting and facilitating a longer working life, by reducing the share of the elderly dependent population, correspondingly reduces the magnitude of the intergenerational transfer that is needed as a population ages.

Third, government policies in the sphere of health care can both increase the capacity of individuals to participate in the labor force during part of their elderly years and reduce the financial burden of medical care to be borne by the elderly during their retirement. They can achieve the latter objective by enabling the elderly to earn income to pay for medical and long-term care.

Fourth, government policies may seek to encourage a higher rate of fertility or increased immigration, essentially lessening the pace at which the EDR rises.

\section{A. The Macroeconomic Strategy}

Asian countries have had a 'double imperative' in considering their appropriate macroeconomic policy stance. Policies should be supportive of rapid economic growth. They should also recognize that, with an aging population, governments will eventually have to address the challenges associated with a substantial increase in the EDR (see Mason and Lee, forthcoming (2007)). The relative importance of each of these imperatives depends on both a country's proximity to the time when its EDR rises and the extent to which the country's per capita income level is converging to industrial country levels.

\footnotetext{
${ }^{8}$ Note the importance that family transfers have played in Taiwan in supporting elderly populations (see Mason and Lee (2007, forthcoming).
} 
The first imperative for growth underscores the importance of mobilizing resources for development, both domestically and, especially for lower income countries, externally. Such mobilization is usually associated with a deficit in the current account, reflecting investment in excess of savings. It also involves the productive employment of the large pool of potential workers in the working age group. Such a policy should also be accompanied by policies that focus on domestic productivity growth, financial sector reform, and enhanced competitiveness.

The second imperative-which is also linked to the exploitation of the 'demographic dividend'-involves taking advantage of the period when the size of dependent population groups is relatively small, affording the possibility of a high savings rate that can be used to realize higher economic growth through increased productivity and a high investment rate.

In macroeconomic terms, the double imperative implies that one would certainly want to see high investment rates, and possibly also a current account deficit, in the early part of the demographic transition for these countries and that this should be reflected in high growth. As these countries move toward having a large EDR and workers are increasingly in their higher earning years, saving for retirement becomes more important and it should be possible for the countries to run current account surpluses. In effect, a high savings rate associated with the need to reduce the burden of fiscal debt and build up assets (at least in the private sector) - that is, prefunding-becomes a critical imperative. Recognizing the double imperative forces attention not only on growth but also on adopting a strategy for some prefunding of the burden of an aged population in the future.

In this light, it is interesting to consider the sequencing of Asian countries' demographic transition in relation to the aging of the present industrial countries and especially in relation to the aging of other Asian populations. The major industrial countries will soon enter a period when one might expect a shift in their macroeconomic balances towards a current account deficit as their elderly reduce their savings rates or dissave. One might expect that their relative decumulation of assets - whether involving the sale of foreign or of domestic assets - would be matched by offsetting current account surpluses in those countries that are still 15 to 20 years from the time when the demographic structure will shift to become more aged. As noted, this latter group of countries would most likely include Korea, Singapore, Thailand, Malaysia and most importantly, China. Current account surpluses in these latter countries would be the logical counterpart to current account deficits in today's aging industrial countries. At a minimum, the high savings and investment rates observed in these Asian countries would appear appropriate if the focus is on meeting the challenge of dealing with the future aging of their populations.

However, other key Asian countries, notably India, Indonesia and the Philippines, are much further from the time when their demographic structure will include a substantial share of the elderly. For them, the growth imperative dominates the effect of the demographic dividend issue in terms of a higher domestic savings rate. It would thus be appropriate to see these countries run current account deficits, reflecting the pressures for investment for growth. Given their lower income levels, the pressures are less for mobilizing savings to prefund a 
period, still far in the future, when their populations will be aged. Thus, one might see the aforementioned earlier group of aging countries of Asia eventually financing investments in (or buying the investment assets of) not only the industrial West, as its population structure is more heavily weighted with elderly groups, but also the later-aging countries of Asia.

An interesting issue to speculate upon is whether this sequenced strategy for dealing with the aging of a population will continue to be applicable a few decades into the future, when the populations of the large countries of South and Southeast Asia themselves begin to approach the decade before they are aged. At that point in the future, suppose one observes these countries also ratcheting up their savings rates, including possibly accumulating external assets from both present industrial countries and those countries in early-aging Asia that have begun to be aged as well. The challenge that will confront the global macro economy then will be the relative buoyancy of the remaining younger population countries in South Asia, the Middle East and Sub-Saharan Africa and the perceived profitability of investments in those regions.

\section{B. Microeconomic Strategies}

Only three of the countries under examination-Korea, Singapore and perhaps Malaysiacan be said to have social insurance systems that are sufficiently universal in coverage that their design features can be evaluated for robustness or adequacy in addressing the needs of a future aged population. The operative questions are: whether these systems ensure that the replacement incomes of most households, in retirement, are adequate to meet the implied standard of living; whether they will prevent the destitution of the most vulnerable elderly; and whether the elderly will have access to a reasonable standard of medical and long-term care, given the limits that may pertain to accessing the most advanced possibilities of medical science (see Asher and Nandy, 2006a). Examining the strengths and weaknesses of the three systems from this perspective highlights the issues that the other Asian countries still need to address. Such an assessment reveals how far Asian countries are from a comprehensive policy framework to address the intergenerational challenges inherent in an aged population.

Korea: In principle, its largely PAYGO pension and social health insurance system should be the most responsive to the challenges of an aged population. Yet it has a key weakness mirroring that of many industrial countries, viz., that its pension promises, in terms of the replacement rate at the current age of eligibility for retirement, are too generous, implying a fiscally unsustainable position. Estimates suggest that Korea's pension fund will be exhausted by 2047, forcing painful policy choices between higher contribution rates, lower benefits, or a postponement in the retirement age.

Korea's medical-care system does not overcommit the amount of generally available benefits it offers. The operative question is more whether it can sustain the greater financial pressures that may arise as the population ages, given that higher medical costs may occur years after the initial retirement age, when pension outlays need to be financed. Over time, a larger share of the elderly will eventually give rise to demands for more care, in part because of the higher costs of dealing with chronic health conditions, and to demands for available 
sophisticated medical technologies. Yielding to these demands will progressively strain the finances of Korea's social health insurance system, increasing the burden on taxpayers and forcing higher contribution rates. It will also probably result in larger out-of-pocket costs for retirees, lowering their effective income replacement rate or forestalling access to needed medical services. ${ }^{9}$

The lesson of Korea for other Asian countries is not the inappropriateness of the basic social insurance approach. Rather it is the importance of having a system design in which parameters (replacement rate, age at retirement, indexation provisions, etc) and policy controls (eligibility for specific medical services, copayment rates, etc) are set with consideration of financial sustainability in mind, and with due regard to the possibility of such downside risks as greater longevity or lower interest rates. The fact that many countries have not yet moved to a universal system can be seen as an opportunity in the sense that the design of a system can still take account of the implications of an aging population. But even this advantage is tempered by the fact that for the limited share of workers currently covered under the existing social insurance systems in those countries, the underlying system design (policy parameters, etc) may prove financially unsustainable if extended more broadly within the population. This implies the need for structural reforms of some key parameters of the social insurance system.

Singapore and Malaysia: These countries are similar to Korea in their use of a provident fund approach for pensions, implying a DC system that is fully funded. Among the key challenges they face-as would other Asian countries considering such a DC strategy-is to ensure that their mandated savings rate is high enough to allow for a sufficient accumulation of assets by the time the population becomes aged so as to provide an adequate replacement income thereafter, and to ensure that the provisions of the system will not allow the funds to be withdrawn too early. ${ }^{10}$ The two principal risks, almost all borne by households, are longevity risk, the possibility that the accumulated assets may prove insufficient to yield an adequate replacement rate over a longer life span, and market risk, lower than anticipated yields from investments during the accumulation phase prior to retirement, and/or inadequate real returns on assets during retirement, or both. ${ }^{11}$

\footnotetext{
${ }^{9}$ Thailand's system also does not appear well designed for long-term fiscal sustainability, despite the fact that it provides for a low replacement rate.

${ }^{10}$ Already there is concern in Singapore about this challenge. News reports note that many elderly are participating in low-wage service industry jobs to supplement their incomes, and that accumulations derived from the low salaries paid in the 1960's and 1970s are not sufficient to keep up with the cost of living. They also emphasize that housing prices have fallen by 30 percent since the mid-1990s, so that the value of retirees' accumulated assets has shrunk significantly (see Burton 2006).

11 Thailand's provident fund also at present encourages lump sum payments at retirement; all of the longevity and market risk are on the backs of the retiree. One aspect of the market risk relates to the potential for housing prices to fall or soften in real terms. This has already proven a problem in Singapore. Some have speculated about the potential for an oversupply of housing if many people try to sell all at the same time.
} 
Other important issues concerning the operation of a DC system relate to the management and investment of the accumulated funds and the availability of a well-developed market in annuity products for the retired population. In small countries, international diversification of assets and hedging by the provident funds may be an appropriate strategy, particularly if domestic financial markets are underdeveloped. Diversification becomes attractive to the extent that the government maintains a conservative fiscal stance, such that the market for government securities is very thin. But international diversification carries risks. Singapore and Malaysia have opted largely for centrally managed investment portfolios, balancing domestic and now external investments. In both cases, while financial governance appears sounds, some concerns have been expressed in varying degrees by critics, inter alia, on grounds of a lack of transparency and political interference in investment decisions. Moreover, the annuity market, particularly in Malaysia, appears to be relatively underdeveloped. And in common with similar systems, annuity purchase rates are very low, reflecting that the decision to purchase annuities is voluntary. Finally, like other countries that have adopted DC systems, neither country appears to have fully addressed the complex issue of what type of social safety net should be established to prevent elderly destitution and how it should be financed. This is an issue still to be tackled by most Asian countries with aging populations.

In the area of medical care, Singapore and Malaysia provide useful cautionary lessons for other Asian countries. Malaysia still has a largely budget-financed medical care system, one that has been relatively effective. It is now considering a move to allow a greater role for private health insurance. The government system allows for greater control in determining the quality and quantity of available services and technology, the magnitude of remuneration of health care practitioners, the possibilities of quantity discounts from pharmaceutical suppliers, and the use of generic drugs. But budget-financed systems can also be subject to administrative challenges and political economy pressures in setting budgetary aggregates. In considering a greater role for private health insurance, the government in principle has scope to regulate the operation of the private system to ensure the operation of a global budget constraint that would limit overall spending on health care in the economy. But opening up the system to private insurance needs to be carefully controlled to limit pressures that push up costs and to address the sources of market failure in the health-care sector. Indeed, Malaysia already has experienced significant brain drain from the public to the private sector, worsening the quality of care and creating cost pressures in the public health system. Care will also need to be taken to structure the insurance market to obtain a reasonably broad risk pool so as to avoid adverse selection pressures that would prevent people in poorer health from obtaining coverage.

Singapore, in contrast, has a largely private system, where out-of-pocket spending dominates, and the key operative assumption is that supply restrictions and demand restraint by households, which are required to bear a significant proportion of costs, will limit the extent of cost inflation and demand pressure. By mandating savings for medical care, the government also forces individuals to prefund some of the cost of catastrophic incidents. But inflationary cost pressures in the health care sector are nevertheless emerging in Singapore. These have not been reflected in a rising medical expenditure share in GDP only because of 
Singapore's rapid economic growth. It remains to be seen whether Singapore's system can be robust to both the pressures of an aging population (with slowing GDP growth) and to the dynamic cost pressures associated with rapid technological change in the medical sector.

China: The government is well aware of the challenges posed by an aging population and have sponsored a number of studies by eminent domestic and outside experts to explore potential policy strategies in the spheres of pensions and medical care. Some of these strategies are reflected in several experiments in selected cities and provinces. Yet for most of China's population, a coherent national strategy for addressing the challenges that will be faced once the population becomes aged remains to be put in place.

With regard to retirement income, although the central government has effected some limited intergovernmental fiscal redistribution across and within provinces, stark differentials remain between the rural and urban sectors, both within and across provinces. These would require major policy initiatives to narrow. The absence of any nationwide social insurance risk pool effectively implies that the differentials would also be manifest in the way in which retirement incomes are financed. So while China is engaged in an effort to raise the level of its per capita income before its population becomes old, the way in which rural and urban GDP is respectively distributed as between the working age and elderly populations remains largely segmented. Even provision for provincial-wide risk pooling would be an enormous start. Centralization from the county and municipal level up to the provincial level, particularly if supported by some equalization and back-up transfers from the center and complemented with provision for some cross-province portability of benefits, would be a desirable initiative.

Under the status quo, this means that the rural aged are essentially relying for their old-age support on their private savings, highly limited transfers from the State, and family support from children still in the rural sector or working as urban migrants (see Yi et al 2006). With only limited social pooling within the rural areas, and a rising EDR, the prospects for significant government support appear limited unless derived from the Central Government, possibly in connection with some form of minimum income guarantee or social safety net scheme. ${ }^{12}$ While higher provincial or local taxes to mobilize revenues would of course be an option, this may prove infeasible on both political economy and incentive grounds.

Although operating at a higher income level, China's urban areas confront perhaps even more difficult pressures. The worsening demographic balance is more acute in the urban areas, particularly for those who are urban residents as opposed to migrants. Current experiments with prefunded DC schemes in fact have amounted to simply an intergenerational transfer scheme (akin to a PAYGO system) whereby the contributions,

\footnotetext{
${ }^{12}$ It is possible that a zero pillar scheme may also contribute to weakening current gender preferences; by creating an alternative form of income support, parents may feel less need to depend on the (traditional) support of sons..
} 
while notionally contributed by working age individuals and saved, are used only partly to build up real assets. The bulk in fact finance payments to existing retirees previously employed in the civil service or state enterprises. This risk of using the funds for other than the DC accounts jeopardizes the viability and sustainability of the DC system.

As already noted, concerns about governance in the investment of these funds is also emerging as a critical issue (as noted above).

As the urban population ages, and the elderly dependency ratio worsens, the relevant policy alternatives are likely to require some mixture of larger contributions and higher tax rates for those formally working in the urban sector (i.e., nonmigrants); a broadening of the coverage and contribution base of such schemes to include young urban migrant workers, thereby deferring somewhat the point at which the fiscal squeeze becomes more acute; greater subsidies by the central government to urban social security schemes possibly involving the transfer of state assets to the system; less generous benefits (e.g., greater reliance on price indexation, more realistic assumptions about life expectancy, more limited returns on available annuities for savings accumulations); an increased eligibility age for pensions, thus effectively delaying the retirement age; introducing a phased retirement; and strengthening the financial sector to enhance the productivity and return of savings, particularly if individual defined contributions are used to accumulate financial assets. ${ }^{13}$ Of course, even more ambitious would be a move to a social security system embodying national pooling.

In the area of medical care, China's government recognizes that an aged population will inevitably involve a greater demand for medical care. But the demand will be compounded by the heavier burden of chronic diseases that are associated with a rapidly urbanizing population. As already noted, while China is not short either of medical practitioners and professionals or of modern medical facilities in the urban areas, the present system of health financing substantially prices out many households in the rural sector and those outside the urban formal sector. The cost of most services and drugs must be paid out-of-pocket, and limited budget support forces rural medical units and urban public hospitals to derive much of their income from such sources. Private care is available but largely on an out-of-pocket basis to those who can afford it. Only those working in viable state enterprises, the government, and some elements of the formal private sector can count on affordable access to medical care.

Formally, the government does not face a challenge of fiscal sustainability arising from the higher costs of medical care associated with an aged population. That is only because its present explicit social health insurance commitments are so limited. The challenge that will

\footnotetext{
${ }^{13}$ The Chinese financial sector needs much strengthening to facilitate the productive use of savings accumulated in DC accounts. At present, it appears that DC contributions in municipalities piloting this type of approach are being used largely to finance current benefit payments to existing retirees, implying effectively a PAYGO system with implicit liabilities for the relevant government unit.
} 
arise will be one of political economy-dealing with discontent from an aging, urbanized population whose increased demand for medical care is unaffordable to many. Potential problems in the future will be exacerbated by the current evolution of the Chinese medical care system in which all the income incentives of those in the medical sector are linked to the prescription of drugs and high-cost modern technologies. Without a mechanism for dealing with the excess supply of beds and health professionals in the urban areas, or for using a global budget constraint to set limits on pricing in the sector (as is done in Japan or Korea), inflationary pressures on medical costs will add to the already large effective burden of medical care associated with an aging population.

The current state of China's system for financing care also has important implications for the third strand of microeconomic policies, that related to enhancing the incentives for and capacity of individuals to participate longer in the work force as their life span increases. Much of China's population still resides and works in the rural sector and is engaged in bluecollar or agricultural work. In urban areas too, many workers have blue-collar jobs, work long hours under difficult conditions and have only a limited capacity to pay for medical care in the event of illness or injury. Rising incomes (which lead to diets high in fat and increased obesity), the rapid pace of urbanization (associated with higher rates of hypertension) and the persistence of adverse unhealthful cultural habits (particularly tobacco consumption), are also increasing the prospective burden and costliness of future illness, although ironically they may lessen the future pension burden by limiting improvements in life expectancy.

A further aggravating factor is widespread environmental pollution, affecting air and water quality. The State Environmental Protection Administration (SEPA) estimates that two thirds of China's urban population live in cities with bad or very bad air quality, which is compounded by the frequency of acid rain. SEPA also estimates that ' 75 percent of the water in the country's seven most important river systems is of a quality unfit for human consumption' (Heymann, 2006, p. 8). The combination of the strains on health arising from the character of much of the work of the labor force, the effects of poor environmental conditions, and the present limited access to medical care by rural and informal urban sector households may make it very difficult for such workers to participate actively in the labor force in their elderly years. ${ }^{14}$

The contrast with Western industrial countries is stark in this regard. In those countries, early retirement in the face of the dramatic improvements in longevity largely reflects social norms and the prevailing generosity of social insurance systems, rather than a physical incapacity to work longer. As a solution to financially unsustainable social insurance systems, policies that create incentives for longer labor force participation (i.e. delayed or phased-in retirement) and low unemployment rates would appear to be not only appropriate but feasible. For China,

\footnotetext{
${ }^{14}$ These issues are also relevant to India. The Community Environmental Monitors, an independent environmental and health agency in India, estimates the enormously high levels of toxic gases and chemicals in the atmosphere affecting Indians in both cities and villages (New York Times, June 4, 2006).
} 
with its rapid catching up in income and urbanization, strengthened preventive health policies and improved access to medical care in the present may be a critical prerequisite for the country's future elderly to be able to function effectively in the labor force and to postpone the age of retirement. In effect, current weaknesses in health policies may narrow China's future policy options for financing its aging population.

\section{FinAl OBSERVATIONS}

The report card on Asia's preparedness for an aging population is decidedly mixed. Most Asian countries are pursuing policies supportive of rapid income growth that will enlarge the size of the income pie available for financing higher living standards at the time their populations become aged. Most have also pursued a policy of fiscal consolidation, reducing public debts and providing flexibility to absorb greater burdens of public spending in connection with their aging population in the future and also providing fiscal space to deal with inevitable uncertainties in the pace of aging and its fiscal consequences. With the exception of China and perhaps Korea, most of the countries face only a limited level of implicit debt associated with existing social insurance obligations.

It is in the sphere of social insurance for pensions and health and of labor market policies where much effort is still needed to create a policy framework that can accommodate the challenges of an aging population. With the exception of Singapore, there is little evidence of policies to create incentives for a longer participation in the labor force. ${ }^{15}$ Indeed, in China, the overwhelming priority to address widespread unemployment has led to pressures for early retirement at age 55 for women and age 60 for men. Asian countries cannot be faulted too seriously for this neglect, since Western industrial countries themselves have moved only slowly to remove disincentives for a longer working life. Moreover for the current elderly of Asia, postponing the retirement age may prove difficult because their health status may suffer from more arduous earlier working lives.

The policy imperative however, should be to ensure that, as more comprehensive social insurance systems are in put in place, existing systems are reformed in some key policy provisions. These include a gradual deferral in the age of eligibility for retirement benefits; actuarial neutrality in linking benefit levels to the length of the prospective retirement period; adequate incorporation, in benefit calculations, of the prospective longevity of cohorts at the time of retirement; a move to payout methods that provide for income payouts rather than lump-sum payments; and restrictions on the use of funds before retirement. As noted for the case of China, addressing the current health care challenges of increasing access to medical care and changing unhealthy behavior related to diet, tobacco consumption and exercise may be critical; and successful interventions could have a high payoff in future years by improving the quality and capacity of an aging labor force.

\footnotetext{
${ }^{15}$ Singapore is seeking to provide incentives to employers to hire the elderly, including policies to reduce wages for workers above age 60 .
} 
Most of the social insurance systems that have emerged in Asia have not been designed with the anticipation of an aged population, suggesting that these countries will face difficult issues of intergenerational burden sharing and complex ethical issues associated with medical-care options for the elderly. The contrast between India and China is particularly striking. India's social insurance system is still minimal, both in its limited coverage of the population in any type of pension system and in the dominance of its private medical care system. Because its population is still in the early stages of aging, it has a much wider window of opportunity for policy decisions than does China. It can design a new system for social health and retirement insurance that takes account of the prospects of an aging population. China, in contrast, has far less time available to develop such a solution. Perhaps because of the collapse of its previous social insurance system and the government's acute awareness of the rapidity of the aging process, one can observe most clearly there the effort to grapple with the challenge of a rapidly aging population.

And yet China also illustrates how difficult this can be, and the looming deficiencies that still need to be addressed. There and elsewhere in Asia, social-insurance systems will have to grapple with the design of a zero-pillar safety net scheme to address the needs of the large number of the elderly who have resided in the urban informal sector or the rural sector, outside the coverage of formal social insurance schemes. Long-term care will also be a serious burden that is not on the radar screens of any Asian countries other than Singapore and Korea. With increasing longevity, an important segment of the population may be subject to long periods of disability and with shrinking family size and a large share of 'single' elderly households, the burden of these groups will need to be addressed in some way. $^{16}$

Finally, it is worth noting that other approaches may need to be part of the arsenal of policy choices to which Asian governments turn as they consider the combination of policies to address an aging population. ${ }^{17}$ For example, China, faced with an inadequate pension system for rural households, may wish to consider allowing the transfer of ownership rights to rural land, endowing those households with additional assets to finance their retirement. In some rural areas, the value of the land may be significant. Even for the many parts of China where rural land is of limited value, better ownership rights may facilitate consolidation of rural land plots, thereby raising returns to the labor remaining in the rural areas and fostering further rural-to-urban migration. Strengthening financial institutions and markets would allow greater productivity to be achieved on the savings accumulated by households for retirement. Encouragement of some emigration may allow a segment of the elderly population to be supported by remittances from family members. In the sphere of health care, coordinated policy actions across sectors, including education, urban planning and the environment, may be needed to promote healthy lifestyles and reduce the burden of chronic diseases.

\footnotetext{
${ }^{16}$ Singapore has probably given the most thought to these issues (see Singapore Committee on Ageing Issues, 2006).

${ }^{17}$ Such issues are explored with considerable wisdom in a recent paper by Dr. Rakesh Mohan (2004).
} 


\section{REFERENCES}

Asher, M., N. Barr, P. Diamond, E. Lim, and J. Mirrlees, 2005, Social Security Reform in China: Issues and Options (unpublished) http://econwww.mit.edu/faculty/download pdf.php?id=1176

Asher, M., and A. Nandy, 2006a, "Health Financing in Singapore: A Case for Systemic Reforms,” International Social Security Review, Vol. 59, No. 2 (January), pp. 75-92.

, 2006b, Social Security Policy in an Era of Globalization and Competition: Challenges for Southeast Asia (unpublished) (see http://econwww.mit.edu/faculty/download pdf.php?id=1176)

Bloom, D., and Canning., 2005, “Global Demographic Change: Dimensions and Economic Significance,” in Global Demographic Change: Economic Impacts and Policy Challenges (Kansas City: Federal Reserve Bank of Kansas City) pp. 10-56.

Blumenthal, D., and W. Hsiao, 2005, "Privatization and its Discontents: the Evolving Chinese Health Care System,” New England Journal of Medicine, vol. 353, no. 11 (September), pp. 1165-70.

Burton, J. (2006), “Straits Under Strain: Why Inequality Is Centre Stage in Singapore’s Election,” Financial Times (May 4), p. 11.

Chaiyasoot, N., 2005, Key Policy Issues in Establishing National Pension Fund, (July). http://www.oecd.org/dataoecd/57/7/34745398.pdf

Committee on Ageing Issues, Singapore, 2006, Report on the Ageing Population. http://www.mcys.gov.sg/successful ageing/report/CAI report.pdf

Heymann, E., 2006, Environmental Sector China: From major building site to growth market' (Deutsche Bank Research, February 28) http://www.dbresearch.com/PROD/DBR INTERNET ENPROD/PROD0000000000196788.pdf.

Jackson, R., and N. Howe, 2004, The Graying of the Middle Kingdom, Center for Strategic and International Studies (Washington)

Jowett, M., 2005, Implementing Universal National Health Insurance: The Case of the Philippines, (prepared for the World Bank Flagship Course, June 2005).

Kim, M.K., 2005, The Korean Health Insurance System: Opportunities and Challenges http://www.issa.int/pdf/seoul05/kang.ppt 
Koh, M.J., 2005, Overview of Korean Retirement Pension Plan, (unpublished Power Point presentation) www.oecd.org/dataoecd/56/38/34723005.PDF

Mason, A., and R. Lee, 2007, “Transfers, Capital, and Consumption over the Demographic Transition,” forthcoming in conference volume of the Nihon University Population Research Institute (Tokyo).

Mohan, R., 2004, “Fiscal Challenges of Population Aging: The Asian Experience,” Global Demographic Change: Economic Impacts and Policy Challenges, Symposium Proceedings (Federal Reserve Bank of Kansas City), pp. 299-368.

New York Times, 2006 “Indian Air is Highly Polluted, Study Finds,” (June 4, 2006), p. 14.

Pi, D., 2005, Developments in Public Old-Age Benefit Schemes (unpublished) http://www.issa.int/pdf/seoul05/2dehai.pdf

Pillay, S., 2005, “Can We Afford to Fall Sick?”, Aliran Monthly, Vol. 25, Issue 4 (see http://www.aliran.com/oldsite/monthly/2005a/4e.html).

Tang, S., X. Cheng, and L. Xu, 2003, Developing Urban Social Health Insurance in a Rapidly Changing Economy of China: Problems and Challenges, http://www.shiconference.de/downl/Session\%202\%20Abstract\%20Dr\%20Shenlan\%20Tang.pdf

Tangcharoensathien, V. and P. Prakongsai, W. Patcharanarumol and P. Jongudomsuk, 2005, Universal Coverage in Thailand: The Respective Roles of Social Health Insurance and Tax Based Financing (December); Power Point presentation; http://www.shiconference.de/downl/Session\%204\%20Abstract\%20Dr\%20Tangsaroensathien.pdf

Thillainathan, R., 2004, Pension and Financial market Reforms and Key Issues on Governance (unpublished) http://www.ier.hitu.ac.jp/pie/Japanese/discussionpaper/dp2003/dp197/text.pdf

Trinh, T., 2006, China’s Pension System (Frankfurt: Deutsch Bank Research) http://www.dbresearch.de/PROD/DBR INTERNET DEPROD/PROD0000000000196025.pdf

United Nations Health Partners Group, 2005, A Health Situation Assessment of the People's Republic of China (July) http://www.wpro.who.int/NR/rdonlyres/0267DCE8-07AB437A-8B01-03D474D922CD/0/hsa_en.pdf

United Nations Population Division, 2005, World Population Prospects: The 2004 Revision Population Database, New York: Department of Economics and Social Affairs of the United Nations Secretariat. 
, 2006, World Urbanization Prospects: The 2005 Revision Population Database, New York, Department of Economics and Social Affairs of the United Nations Secretariat.

Wagstaff, A., 2005, “Health Systems in East Asia: What can Developing Countries Learn from Japan and the Asian Tigers," World Bank Policy Research Working Paper No. 3790 (December).

World Health Organization, Regional Office for South-East Asia, 2004, Regional Overview of Social Health Insurance in South-East Asia (New Delhi). , Macroeconomics and Health China Report, 2005, (unpublished) (Geneva)

Yang, B., 2005, National Health Insurance in South Korea: Opportunities and Challenges (unpublished). (presented at International Symposium on Achievements and Challenges of National Health Systems, Taiwan (March).

Yi, Zeng, Z. Wang, J. Leiwen, and D. Gu, 2006, “Projection of Family Households and Elderly Living Arrangement in the Context of Rapid Population Aging in China-A Demographic Window of Opportunity until 2030 and Serious Challenge Thereafter" (unpublished) (forthcoming in GENUS).

Yip, W. and W. Hsiao, 2001, Economic Transition and Urban Health Care in China: Impacts and Prospects, (unpublished) Annex http://www.eldis.ids.ac.uk/static/DOC18920.htm 


\section{Appendix I. Summary Characteristics of Asian Pension and Health Care Systems}

\begin{tabular}{|c|c|c|}
\hline & Pension System & Health System \\
\hline $\begin{array}{l}\text { People's } \\
\text { Republic of } \\
\text { China }\end{array}$ & $\begin{array}{l}\text { Rural residents: no effective pension system other } \\
\text { than small transfers from localities. } \\
\text { Urban residents: Gradual transition underway from } \\
\text { responsibility by individual state enterprises and } \\
\text { municipal governments to pooled system at municipal } \\
\text { and provincial levels (National Social Security Fund). } \\
\text { Presently largely unpooled beyond the provincial } \\
\text { level and fragmented, covering only } 1 / 3 \text { of urban } \\
\text { work force, and with significant noncompliance by } \\
\text { many new enterprises. The new system includes: a } \\
\text { mandatory defined benefit (DB) pay-as-you-go } \\
\text { (PAYG) pillar financed by contributions from } \\
\text { employees and employers (13 percent of wages); a } \\
\text { funded mandatory 2nd Defined Contribution (DC) } \\
\text { pillar funded by employer and individual } \\
\text { contributions (11\% payroll tax); and a } 3^{\text {rd }} \text { pillar } \\
\text { supplementary saving plan. The latter has recently } \\
\text { been extended to all urban workers. There is no } \\
\text { pooling on a national basis. In principle, the } \\
\text { replacement rate would be about } 20 \text { percent of the } \\
\text { average provincial wage. } \\
\text { Individual account funding is largely notional, with } \\
\text { contributions in fact used by municipal governments } \\
\text { to finance liabilities to existing retirees. Funded } \\
\text { savings earn low rates of return on domestic bonds } \\
\text { and bank deposits. Some experiments (Liaioning } \\
\text { Province) to introduce genuine funding with } \\
\text { provincial pooling and with coverage extended to } \\
\text { rural contractual workers, self-employed, and private } \\
\text { firm employees. }\end{array}$ & $\begin{array}{l}\text { Government hospital and clinic system severely } \\
\text { underfinanced by governments, such that effective } \\
\text { access is highly inequitable, being contingent on ability } \\
\text { to pay out-of-pocket for most services and drugs. There } \\
\text { exists a significant differential in the availability of } \\
\text { health care services as between urban and rural areas. } \\
\text { Although charges for basic services are in principle } \\
\text { publicly regulated, private and public hospitals, } \\
\text { particularly in urban areas, are motivated to mobilize } \\
\text { revenues by acquiring modern technologies and } \\
\text { charging for these as well as pharmaceuticals. } \\
\text { Urban: Initiatives are underway to provide basic } \\
\text { medical insurance (BMI) for urban employees in the } \\
\text { formal sector (though not for migrant workers from the } \\
\text { rural areas), through medical savings accounts and some } \\
\text { risk pooling within an urban area. But there is no wider } \\
\text { pooling of risks. Benefit coverage is limited and there } \\
\text { are still significant out-of-pocket costs for significant } \\
\text { medical episodes, particularly for the poor. About one } \\
\text { third of the urban population is covered by BMI } \\
\text { schemes, and one half of urban residents is uncovered } \\
\text { by health insurance. Cross- subsidization by } \\
\text { contributors to elderly retirees is also proving costly to } \\
\text { the system. } \\
\text { Rural: Only a small fraction of rural residents have } \\
\text { access to the new rural cooperative medical insurance } \\
\text { scheme, which is voluntary in coverage, subject to } \\
\text { adverse selection problems, and limited in benefits. } \\
\text { Also China is experimenting with initiatives to establish } \\
\text { subsidized community health centers. In some cases, }\end{array}$ \\
\hline
\end{tabular}




\begin{tabular}{|c|c|c|}
\hline & $\begin{array}{l}\text { The state (municipalities) is largely responsible for } \\
\text { liabilities to those urban retirees that accrued pension } \\
\text { rights under previous system. }\end{array}$ & $\begin{array}{l}\text { some basic medical insurance fund managements have } \\
\text { started to use DRGs or fixed-fee-for-service schemes to } \\
\text { pay for inpatient services. }\end{array}$ \\
\hline $\begin{array}{l}\text { Hong Kong } \\
\text { SAR }\end{array}$ & $\begin{array}{l}\text { Comprehensive Social Security Assistance (CSSA) } \\
\text { Old Age Allowance (OAA) is a means-tested } \\
\text { scheme, both with respect to income and assets. Both } \\
\text { CSSA and OAA are funded by general revenue and } \\
\text { are noncontributory } \\
\text { Mandatory Provident Fund (MPF), established in } \\
\text { 2000, is the main pension vehicle; it is fully funded } \\
\text { and privately managed and allows citizens to select } \\
\text { investment plans from a large number of private } \\
\text { investment funds. } \\
\text { Civil Service Provident Fund Scheme is a DB } \\
\text { pension scheme but civil servants allowed to } \\
\text { participate in the MPF (which is DC). }\end{array}$ & Health care is principally delivered by the public sector. \\
\hline India & $\begin{array}{l}\text { Employee's Provident Fund-a funded program } \\
\text { with features of both DB and DC schemes. There is } \\
\text { also a Employees' Pension Scheme and a } \\
\text { Employees' State Insurance. } \\
\text { Only about } 10 \text { percent of work force is covered by the } \\
\text { formal social security system. The public sector } \\
\text { pension system is significantly unfunded, with } \\
\text { unfunded pension liabilities at } 25 \text { percent of GDP. }\end{array}$ & $\begin{array}{l}\text { Government provided medical care (clinics and } \\
\text { hospitals) accounts for no more than } 17 \text { percent of } \\
\text { spending on health. Social health insurance (Employees } \\
\text { State Insurance Scheme (ESIS) and Central } \\
\text { Government Health Scheme (CGHS)) mainly covers } \\
\text { civil servants and a certain proportion of employees in } \\
\text { the formal sector (roughly } 10 \text { percent of the total } \\
\text { population). Private health insurance is negligible but } \\
\text { growing rapidly (WHO, 2004, p.16). Out-of-pocket } \\
\text { payments account for } 83 \text { percent of health expenditure. } \\
\text { Most of the population has poor access to good quality } \\
\text { of care. Some new initiatives (Janraksha Scheme; } \\
\text { Community Based Universal Health Insurance Scheme) }\end{array}$ \\
\hline
\end{tabular}




\begin{tabular}{|c|c|c|}
\hline & & are being introduced to provide care to the poor. \\
\hline Indonesia & $\begin{array}{l}\text { Provident fund applies to workers employed in firms } \\
\text { of } 10 \text { or more employees, but self-employed } \\
\text { excluded. Provident fund withdrawals at age } 55 \text {. }\end{array}$ & $\begin{array}{l}\text { Government health facilities, financed from the budget, } \\
\text { are a major source of inpatient and outpatient care for } \\
\text { much of the population. Some social health insurance } \\
\text { and social safety net schemes also operate, which cover } \\
\text { no more than a fifth of the population. } \\
\text { PT Askes Scheme: mandatory health insurance } \\
\text { coverage for civil servants, pensioners, and military } \\
\text { personnel of public and semipublic establishments } \\
\text { (payroll tax funded); covers } 7 \text { percent of the population. } \\
\text { Care provided through government health centers and } \\
\text { hospitals as well as private hospitals. Providers paid on } \\
\text { prospective payments basis; but significant costs borne } \\
\text { on an out-of-pocket basis. } \\
\text { PT Jamsostek: a mandatory noncontributory insurance } \\
\text { scheme for all private employers with } 10 \text { or more } \\
\text { employees, mostly in the formal sector, with benefits } \\
\text { for inpatient and outpatient care and drugs. Care is } \\
\text { provided by health care providers contracted directly or } \\
\text { indirectly by PT Jamsostek. An opt-out provision allows } \\
\text { employers to contract with other insurance providers, } \\
\text { resulting in an adverse selection problem. PT Jamsostek } \\
\text { covers only about } 5 \text { percent of eligible employees. } \\
\text { Social Safety Net programme: one scheme provides } \\
\text { financial assistance to ensure the poor are able to get } \\
\text { access to essential health care, with a focus on high-risk } \\
\text { pregnant mothers; another provides block grants to } \\
\text { health centers to supplement supplies provided by the } \\
\text { Ministry of Health; New Askeskin system covers } 60 \\
\text { million low-income individuals nationwide, providing } \\
\text { comprehensive health services for the poor as well as } \\
\text { government employees (a managed care concept). }\end{array}$ \\
\hline
\end{tabular}




\begin{tabular}{|c|c|c|}
\hline & & $\begin{array}{l}\text { Contributions paid by government on the basis of the } \\
\text { number of individuals covered. Primary health care is } \\
\text { provided at health centers, subhealth centers, with } \\
\text { referral from primary health care provider required to } \\
\text { access secondary care. } \\
\text { Proposals are presently being considered for a } \\
\text { broadened form of National Health Insurance. }\end{array}$ \\
\hline Korea & $\begin{array}{l}\text { National Pension System of Korea covers } 81 \\
\text { percent of active population and is largely a } \\
\text { contributory (employee and employer) PAYGO, DB } \\
\text { pension plan. The earnings replacement rate is about } \\
60 \text { percent for average income earners with } 40 \text { years' } \\
\text { contribution, with a retirement age of } 65 \text {. Separate } \\
\text { Special Occupational Pension for government } \\
\text { employees, private teachers, and military personnel. } \\
\text { Also a } 2^{\text {nd }} \text { Pillar (Severance Payment System) equal to } \\
\text { lump sum relating to number of years of service times } \\
\text { the average monthly salary of last } 3 \text { months. } \\
\text { New Employee Retirement Benefit Security Act (to } \\
\text { take effect in 2006): involves choice of severance } \\
\text { payment (old scheme); DB or DC plan. The choice is } \\
\text { based on agreement between the employer and } \\
\text { employees; also provides for an IRA. } \\
\text { Problems relate to irregularly employed workers who } \\
\text { have to subscribe to the National Pension Plan- } \\
\text { relates to microbusiness owners and nonregular } \\
\text { workers (daily workers, dispatched workers, service } \\
\text { workers). The latter relates to perhaps one third of } \\
\text { workers. } \\
\text { Presently it is estimated that as of 2005, } 78 \text { percent of } \\
\text { people aged } 60 \text { and over do not receive national }\end{array}$ & $\begin{array}{l}\text { Social Health Insurance (SHI) Scheme: single payer, } \\
\text { mandatory scheme with payroll contributions. Coverage } \\
\text { is almost universal ( } 96 \text { percent of population), with } \\
\text { remainder covered by medical aid programme for the } \\
\text { poor (fully subsidized by government general } \\
\text { revenues). SHI regulates prices charged by caregivers } \\
\text { and institutions. Care largely provided by private sector, } \\
\text { with cost borne by Scheme but with significant } \\
\text { copayments ( } 25 \text { percent for inpatient; } 35 \text { percent for } \\
\text { outpatient). Presently, physicians can do "balance } \\
\text { billing” but it is not actively promoted. No use of } \\
\text { primary care physicians as gate keeper. Out-of-pocket } \\
\text { expenditures on health is about } 47 \text { percent of total } \\
\text { health expenditure. Authorities presently considering } \\
\text { the extent to which private insurance should be allowed } \\
\text { to absorb the cost of copayments and whether balance } \\
\text { billing is allowable. } \\
\text { Efforts are being made to separate prescription and } \\
\text { dispensing of drugs in order to contain costs. } \\
\text { Government has been fairly restrictive in terms of } \\
\text { service coverage, thus not allowing many new } \\
\text { technologies under coverage of the plan (e.g., } \\
\text { ultrasound, and some nuclear therapies). There are signs } \\
\text { of movement however to achieve more comprehensive } \\
\text { benefit coverage in the future. Presently, individuals }\end{array}$ \\
\hline
\end{tabular}




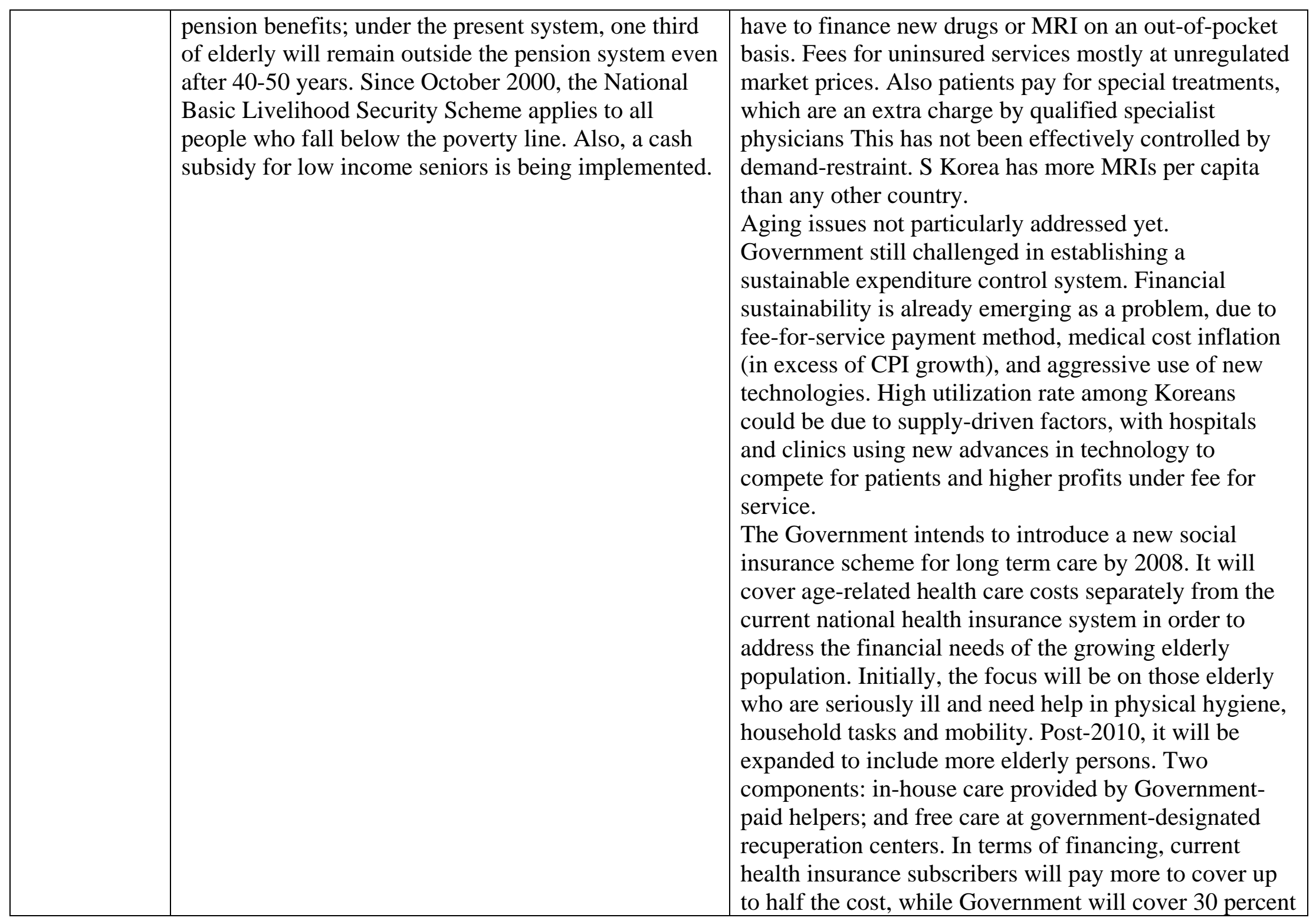




\begin{tabular}{|c|c|c|}
\hline & & $\begin{array}{l}\text { of the burden; copayments by beneficiaries will cover } \\
20 \text { percent of the cost, except for the poor. }\end{array}$ \\
\hline Malaysia & $\begin{array}{l}\text { The Employee's Provident Fund (EPF) is a national, } \\
\text { compulsory funded savings scheme for private sector } \\
\text { and nonpensionable public sector employees (with } \\
\text { accumulated assets of about } 56 \text { percent of GDP). } \\
\text { Apart from withdrawals for retirement (at age 55), } \\
\text { preretirement withdrawals are allowed for home } \\
\text { ownership, education and medical care. Most retirees } \\
\text { take accumulated savings at retirement in a lump sum. } \\
\text { Civil servants are covered by a largely funded DB } \\
\text { plan run by the Government Pensions Department. } \\
\text { About } 42 \text { percent of the labor force is not covered by } \\
\text { a retirement scheme. About } 10 \text { percent of EPF's } \\
\text { investments are outsourced to external equity and } \\
\text { fixed income managers, though this amount will be } \\
\text { raised to about } 20 \text { percent by } 2008 \text {. }\end{array}$ & $\begin{array}{l}\text { Malaysia has a predominantly budget-financed public } \\
\text { hospital and health center system, with minimal } \\
\text { copayments. The private health care system is growing } \\
\text { and is financed from out-of-pocket payments. } \\
\text { Consideration is presently being given to the } \\
\text { establishment of a National Health Insurance Scheme. }\end{array}$ \\
\hline Philippines & $\begin{array}{l}\text { Social Security System covers } 74 \text { percent of the labor } \\
\text { force: a DB PAYGO scheme financed by } \\
\text { contributions by employers and employees, with } \\
\text { replacement rate of } 48 \text { percent of average contribution } \\
\text { wage. Government Service Insurance System of } \\
\text { the Philippines provides social protection to the } \\
\text { public sector (about } 4 \% \text { of the active working } \\
\text { population). }\end{array}$ & $\begin{array}{l}\text { The Philippines Health Insurance Corporation } \\
\text { (PhilHealth) (established in 1995) covers } 56 \text { percent of } \\
\text { the total population (employees from formal and } \\
\text { informal sector plus retirees and indigent members) } \\
\text { though some estimates suggest coverage as high as } 80 \\
\text { percent. It is financed by payroll deductions and general } \\
\text { tax revenue (though noncompliance in contributions is a } \\
\text { significant problem). Benefits include inpatient care } \\
\text { (limited coverage), drugs and outpatient care. Payments } \\
\text { are based on fee for service and case payment } \\
\text { reimbursement model, resulting in "cost escalation, } \\
\text { overcharging, excessive admissions and irrational use of } \\
\text { drugs.” (WHO 1974, p. 35). Also said to be "high } \\
\text { administrative costs (12 percent of total spending) and } \\
\text { ineffective filttering of fraud.” There are significant co- }\end{array}$ \\
\hline
\end{tabular}




\begin{tabular}{|c|c|c|}
\hline & & $\begin{array}{l}\text { payment requirements. Private expenditures on health } \\
\text { were about } 61 \text { percent of total health expenditure in } \\
2002 \text { (with the bulk paid on an out-of-pocket basis). In } \\
\text { terms of provision, about half of inpatient capacity (in } \\
\text { beds) is in government facilities. Public health services } \\
\text { at the primary level delivered through the Rural Health } \\
\text { Unit. }\end{array}$ \\
\hline Singapore & $\begin{array}{l}\text { A mandatory, fully-funded, DC individual account } \\
\text { system organized through the Central Provident } \\
\text { Fund (CPF), involving employer and employee } \\
\text { contributions, with CPF investments determining a } \\
\text { market-oriented yield on contributions. In addition to } \\
\text { CPF individual account accumulations being used for } \\
\text { retirement, they can be used for the purchase of a } \\
\text { home, insurance, or education under defined terms. } \\
\text { The income replacement rate is estimated at } 20-40 \\
\text { percent. Funds can be withdrawn at age } 55 \text {. } \\
\text { Statutory retirement age raised to } 62 \text { from January } 1 \text {, } \\
1999\end{array}$ & $\begin{array}{l}\text { Most spending on health care in Singapore is financed } \\
\text { by private employer-based health insurance and out-of } \\
\text { pocket spending by households. Eighty percent of } \\
\text { inpatient care is provided in public hospitals, while } 80 \\
\text { percent of outpatient care is provided by the private } \\
\text { sector. } \\
\text { Under the CPF, some mandatory saving for medical } \\
\text { care through: } \\
\text { Medisave: a portion of the CPF contributions are } \\
\text { directed to a specific account for use in relation to the } \\
\text { cost of hospitalization and inpatient medical expenses, } \\
\text { with limits on the maximum amount that can be } \\
\text { accumulated in the account. As a source of financing for } \\
\text { health care, it is of marginal importance, accounting for } \\
\text { only } 7 \text { percent of total health care outlays. } \\
\text { Medishield: a backup health insurance programme } \\
\text { based on cross-sectional risk-pooling designed to deal } \\
\text { with catastrophic medical incidents. It is a voluntary } \\
\text { scheme based on the opting-out method, creating } \\
\text { adverse selection problems. Premiums are on a per } \\
\text { individual (not household) basis. Medishield covers } \\
\text { only those under age 80; those over age } 80 \text { are denied } \\
\text { this protection. It does not cover the first seven days of } \\
\text { hospitalization (and perhaps more after } 2005 \text { reforms). } \\
\text { It involves claimable limits, deductibles in every policy }\end{array}$ \\
\hline
\end{tabular}




\begin{tabular}{|c|c|c|}
\hline & & $\begin{array}{l}\text { year, and coinsurance. } \\
\text { Medifund: a social assistance fund set up by the } \\
\text { government as a means-tested social safety net. It is } \\
\text { administered by each hospital and which can be applied } \\
\text { to any indigent person in relation to medical treatment. } \\
\text { ElderCare Fund: an endowment fund, providing } \\
\text { subsidies to voluntary welfare organizations. } \\
\text { ElderShield: a voluntary insurance scheme, based on } \\
\text { the opting-out method for providing long term care. } \\
\text { Singapore seeks to rely on private demand restraint, } \\
\text { coupled with limits on available resources in Medisave } \\
\text { accounts, as a constraining force on medical } \\
\text { expenditure pressures. On average, } 60 \text { percent of } \\
\text { hospitalization costs in public hospitals are subsidized } \\
\text { by the government, with the residual } 40 \text { percent charged } \\
\text { to patients through their Medisave and out-of-pocket } \\
\text { payments. Also, there is a } 20 \text { percent coinsurance on } \\
\text { Medishield expenses. }\end{array}$ \\
\hline Thailand & $\begin{array}{l}\text { The Social Security Office (SSO): established in } \\
\text { 1999, provides for a DB PAYGO contributory } \\
\text { pension system. The Old Aged Pension Fund } \\
\text { (OAPF) covers private employees amounting to about } \\
28 \text { percent of the total labor force. It has a tripartite } \\
\text { contribution schedule. The OAPF covers employees } \\
\text { but not self-employed. It covers about } 7.4 \text { million } \\
\text { persons (excluding self-employed, informal sector, } \\
\text { and teachers in private schools). As a new scheme, } \\
\text { pensions will begin to be paid out in } 2014 \text {. Benefit } \\
\text { coverage rate is low (at around 13-15 percent of the } \\
\text { last month' salary). The replacement rate of OAPF is } \\
\text { still only about } 30 \text { percent for an individual with a full } \\
\text { working life and retiring at } 55 \text { years. The retirement }\end{array}$ & $\begin{array}{l}\text { Three schemes operate: } \\
\text { Civil Servant Medical Benefit Scheme: for } \\
\text { government employees, retirees, and dependents: } \\
\text { financed from general tax revenues (fee for service } \\
\text { reimbursement model); covers } 10 \text { percent of the } \\
\text { population. } \\
\text { Social Health Insurance: covers private sector } \\
\text { employees-a contributory scheme with tripartite } \\
\text { contribution (capitation inclusive outpatient and } \\
\text { inpatient): covers } 13 \text { percent of the population } \\
\text { Universal Coverage Scheme: covers remaining } \\
74 \text { percent of the population, financed from general tax } \\
\text { revenues (noncontributory) (capitation OP and P\&P } \\
\text { global Budget and DRG for IP). Comprehensive }\end{array}$ \\
\hline
\end{tabular}


age for old-age pensions under the OAPF system is still 55. There is a minimum pension. Some degree of funding (about 2 percent of GDP in 2003), but with a negative cash flow projected after 2026 and the reserve exhausted by 2049 .

There are 2 voluntary DC Provident and Retirement Mutual Funds similar to 401(K) and IRA schemes in the US. These encourage lump-sum withdrawals rather than the purchase of annuities.

Central government employees are provided with a provident fund on a mandatory DC basis in addition to a lump sum from a DB pension. Retirees can get a wage-replacement rate of 70 percent with the GPF.

the retirement age is 60 .

\section{State-owned enterprise employees are either} covered by DB scheme or under a provident fund arrangement.

The government is currently contemplating establishment of a National Pension Fund, which would be a DC funded scheme, with a minimum contribution rate of 3 percent that would cover private employed persons (eventually also the self employed), as well as government, and state-owned enterprise employees. It would not begin until 2007 at the earliest. Initially, it would cover existing Provident Fund members. With a 6 percent contribution rate for NPF (divided equally between employers and employees), it could achieve a 70 percent replacement rate for low-income earners. It would allow participants to select from a limited list of licensed and pre-approved fund managers. coverage with neither deductible nor co-payment at the point of service, but some high technology services are excluded. There are also concerns about capitation payments proving insufficient. With high utilization rates, there is also a concern about the quality of care that can be provided. The scheme has a strong pro-poor bias.

For SHI and UC Schemes, there are contractual arrangements with competing public and private providers, using the capitation-payment method. The SSO and National Health Security Office design packages and payment methods, with a purchaser/provider split.

A quarter of hospital beds are in the private sector. This may be a tier situation, whereby some private hospitals contract with the SHI scheme and the remainder serving households fully paying on a out-of-pocket basis.

Out-of-pocket expenditure was about 30 percent of total health expenditures. 